\title{
The Role of the Cultural and Educational Environment in the Formation of Youth's Regional Identity in Krasnodar Krai
}

\author{
Svetlana Mirontseva \\ The Department of Public Policy and State Administration \\ The Faculty of Management and Psychology \\ Kuban State University \\ Krasnodar, Russia \\ E-mail: mirontseva@mail.ru
}

Igor Bashmakov

The Department of Public Policy and State Administration The Faculty of Management and Psychology

Kuban State University

Krasnodar, Russia

E-mail: igorbash87@mail.ru

\author{
Olga Borisko \\ The Department of Public Policy and State Administration \\ The Faculty of Management and Psychology \\ Kuban State University \\ Krasnodar, Russia \\ E-mail: olgbor@mail.ru \\ Alexey Sazantovich \\ The Department of Public Policy and State Administration \\ The Faculty of Management and Psychology \\ Kuban State University \\ Krasnodar, Russia \\ E-mail: vertgalant@mail.ru
}

\begin{abstract}
A theoretical study of youth's regional identity and the cultural and educational environment of a region, influencing the formation of youth's regional identity, is represented in this article. The analysis of such concepts as 'territorial identity', 'regional identity', 'youth's regional identity', 'the cultural and educational environment', 'cultural and educational space of a region', 'the cultural and educational environment of a region' is conducted. The authors formulate their own understanding of the regional cultural and educational environment.
\end{abstract}

The significance of the regional cultural and educational environment and activities of cultural and educational institutions directed at the formation of youth's regional identity are explored in one of Russian regions (Krasnodar krai). The role of traditional and new subjects of the regional cultural and educational environment in the formation of youth's regional identity is substantiated. A focus group research with students and schoolchildren fulfilled by authors in 2017-2018 constitutes the main findings of this paper.

Keywords-youth; regional identity; youth's regional identity; cultural policy; educational policy; youth policy; the cultural and educational environment of a region; cultural and educational institutions; the formation of youth's regional identity

\section{INTRODUCTION}

Nowadays the cultural and educational environment has a great importance for the processes of young people's socialization and perception of values. The crisis of youth's identity may happen in the contemporary world of constant change and hindered transition of moral values between generations. This, in turn, might result in difficulties concerning youth's involvement into social, economic, political and cultural life, and lead to problems of adaptation in modern society and other negative implications (for instance deviant behavior)

The formation of youth's regional identity in the cultural and educational environment of a region is conditioned by the role culture and education play in society. Institutions of education and culture may favor the actualization of young people's interest in historic and cultural values, enhance the level of group territorial identity and increase the tolerance of the young to different social groups, which is important condition for the development of stable regional societies.

For this reason, the study of the cultural and educational environment and particularly the role of cultural and educational institutions in the formation of youth's regional identity is of paramount importance. Especially it is interesting to examine the practice of such multicultural region as Krasnodar krai. Thereby the aim of this article is to analyze specifics and the role of the cultural and educational environment in the formation of youth's regional identity in culturally and ethnically diverse Krasnodar krai.

\section{THEORETICAL BASIS OF THE STUDY CONCERNING YOUTH'S REGIONAL IDENTITY IN THE CULTURAL AND EDUCATIONAL ENVIRONMENT OF A REGION}

In social science identity is a complex of roles and statuses organized adequately to a social system. Territorial or regional identity is one of the types of social identity. The term of regional consciousness, that is close to the notion of regional identity, was developed in human geography in the 1930s. F.W. Morgan in 1939 studied three aspects of 
regional consciousness: the rise of political and social regionalism, the development of the regional concept in geography and the emergence of the 'regional novel' in literature. All three tendencies according to F.W. Morgan started in European scientific and social life in the end of XIX century [1]. Since 1970s the term of regional consciousness has been gradually replaced by the concept of regional (local) or territorial identity. E. Relph in 1976 distinguished two meanings of regional identity: 'identity of' and 'with a place'. Identity of a place is 'a persistent sameness and unity which allows that (place) to be differentiated from others'. Whereas identity with a place is a sense of 'insideness' or 'a degree of attachment, involvement, and concern that a person or a group has for a particular place' [2].

In its second sense the term of territorial identity has been widely used since 1980s in such scientific fields as social and political geography, cultural studies, anthropology, sociology, political science, etc. The concept is now often applied to differently scaled regional communities (from local to macroregional). Regional identity is a complex of symbolic and ideological mindsets and meanings, linked to the interpretation of regional specifics. In this process regional uniqueness becomes tangible in images, symbols and myths, shared by the members of regional community [3]. Emotional bonds with a territory remain significant for contemporary people [4] [5].

The specifics of youth's regional identity are connected with characteristics of the group. Youth is a social and demographic group, directly linked to the reproduction of social relations. Young people at the same time foster their renewal, taking into account social change, and their transition to future generations. These needs and challenges might be related to problems of self-identification and selfawareness as a part of any society, and also they are linked to the creation of new conditions for the formation of young people's regional identity.

Peculiarities of youth's regional identity formation consist in the fact that young people are open in their consciousness and thinking for the perception of values and meanings that are formulated by different actors (family, state, mass media, etc.) and youth itself. J.A. Zubok points out that youth may reproduce value orientation without assistance [6]. Within the scope of regional identity that could be young people's treatment of region, homeland, their assessment of regional governmental activities, approval of power decisions, etc.

Currently there is a variety of scientific approaches concerning the essence and definition of the cultural and educational environment integrally and the regional cultural and educational environment particularly. The term considered is being formed at the junction of such notions as 'the educational environment' and 'the cultural environment'. 'The cultural and educational environment' in modern pedagogy is a complex of learning, cultural and educational conditions of young people's socialization. According to M.P. Artamonova, the cultural and educational environment is a dynamic range of cultural and educational conditions and people, acting under these conditions, which has flexible spatio-temporal limits. This environment enables socialization of individual and at the same time develops as a result of human activities. M.P. Artamonova states that the cultural and educational environment is necessary for the formation of a person, cultural development of people and social groups, the transition of socio-cultural knowledge and skills [7].

E.S. Mertens have done the analytic review of contemporary theories concerning 'the cultural and educational environment' as a complex integral concept used in pedagogy. As a result of theoretical considerations she comes to a conclusion that the cultural and educational environment is an assemblage of educational-learning and educational-cultural conditions that develop and form one's character. The cultural and educational environment reflects the level of political and socio-economic development, existing moral and spiritual features of society, national and historical traditions [8].

I.J. Murzina describes the regional cultural and educational environment as a complex organized integrity consisting of such key elements as cultural and educational structures of society. Both systems translate and actualize meanings, created during social activities of a region, and form people's identity and lifestyle. The researcher also states that the regional cultural and educational environment is a system of coordinates surrounding human activities. Vertical line presents cultural meanings (worldview, moral values, etc.), horizontal line is a geographic space [9].

E.P. Belozercev views the regional cultural and educational environment as a complex integral phenomenon, assisting the study of factors, conditions and instruments of educational-learning process, and treats this environment as an indicator of territory uniqueness and a way of pedagogy practice description, dependent on local conditions of connectivity between 'culture' and 'education'[10].

Thus the authors of this article see 'the regional cultural and educational environment' as a complex phenomenon that includes a dynamic range of educational-learning and educational-cultural conditions of individual's formation, socialization and development (one of the factors is regional identity) with the participation of different actors. The individual, social groups and regional community are all included in this environment, constrained by affecting conditions, where the interaction between socializing individual and regional community, as well as mutual influence among different other actors constantly happens. Educational-learning and educational-cultural conditions have flexible spatio-temporal limits and consist of unique regional characteristics: the level of regional political and socio-economic development, the condition of regional moral and spiritual sphere, cultural values and traditions, the historical and socio-cultural experience of a region, as well as symbolic instruments, reflecting values, traditions and the uniqueness of a region [11]. 
Night of cinema', 'the Night of art' (on these occasions cultural institutions remain open late into the night and invite visitors free of charge). The majority of cultural and educational activities performed during these events are dedicated to history, nature, culture and art of Krasnodar krai. Moreover, educational and cultural institutions try to develop youth's tolerance in such multicultural region as Krasnodar krai. For instance, Museum of E.D. Felitsyn organized the exhibition 'Kuban multifaceted' where the visitors could see the exhibits reflecting cultural and ethnic diversity of the region [12].

Organizational mechanism of youth's identity formation in the cultural and educational environment of Krasnodar krai implies the organization of various events, facilitating the formation of positive image of the region and regional community, which may be attractive for the young. Annually regional forums and discussion panels are held in regional youth camps (one of the most known is 'Region 93'). Participation in such events helps the young by giving them a chance to formulate and express their point of view on issues relating to many aspects of regional social life.

By the way of informational mechanisms informing of young people takes place. The mass media convey the news about all actions relating to history, culture and specifics of Krasnodar krai. Youth web portal of Krasnodar krai is a striking example of this mechanism [13]. On this website created by Krasnodar krai's ministry of education, science and youth policy the young may become acquainted with youth projects and the news about their peers. One of the main annual cultural events in Krasnodar krai is the opening ceremony in ethnic village 'Ataman' which is situated in the place where there once was the first settlement of Zaporozhian Cossacks (since then they begin to be named the Black Sea or Kuban Cossacks). This historical moment nowadays is considered to be very important for regional history [14]. Schools and other educational institutions participate actively in all occasions taken place in this village. Informing occurs by means of the internet and popular social networking services.

In Krasnodar region there are several new actors, participating in the formation of youth's regional identity. These are initiators of popular commercial leisure-time activities for the young. Anti-cafés, for example, are becoming more and more popular with young people. It is a 'free space' for initiative and creative youngsters who collaborate and discuss their projects there. One of new forms to spend leisure time is a quest (adventure game). Another form for the young in Krasnodar, which is the main city of the region, is a walking performance 'My city voce'. It is an excursion during which sightseers walk in the streets and listen (in headphones) to the play based on the history of the city [15]. For instance, one of such shows was dedicated to the topic of the Russian Revolution and Civil War. The company promises a real immersion into the history of the city and the country as well.

In 2017-2018 the authors conducted a qualitative empirical research to clarify the perceptions of students in Krasnodar krai about various aspects of youth's regional takes active part in the organization of such annual state festivals as 'Library night', 'the Night of museums', 'the 
identity formation in the cultural and educational environment of the region. The study was fulfilled in the form of a focus group interview with schoolchildren from municipal districts of Krasnodar krai and students of regional universities. 10 focus groups with 10 to 15 participants in each group were held. During sessions many issues were discussed, including the importance of regional identity formation, factors influencing the process, as well as features, subjects, mechanisms and technologies of the process in Krasnodar region.

In this article based on the results of this empirical study we focus on the role of cultural and educational institutions in the formation of youth's regional identity in Krasnodar region. Young people (both schoolchildren and students) admit that state and municipal authorities in Krasnodar region organize a lot of activities for the young, but they name family, cultural and educational institutions as main subjects of regional identity formation.

Schoolchildren and students believe that young people's regional identity is formed by regional authorities through the educational system primarily. According to respondents, initial knowledge about the region should be obtained in childhood while studying at elementary school, "when such concepts as "freedom", "love", "love to a small homeland" begin to form', 'first and second grades - the children are very small and active'. Youngsters consider that the process should be natural. Knowledge and values should not be dictated. At the same time young people mention some problems linked with teaching of 'Kubanology': 'It always depends on the teacher whether the discipline is interesting', 'Everything depends on the teacher. If the way of teaching is interesting, children go on excursions with the teacher, then the subject is interesting'.

Answering the question 'What might be done to make such subjects more interesting?', young people name popular adventure game - quest. 'It is easier to learn history though the game', 'there are excursion plays 'My city voce' in Krasnodar, during these plays one can study the history of hometown, it is interesting'. Respondents point out that the young easily acquire knowledge during such games. Young people are not only ready to take part, but also organize quests. Many students already have the experience of organizing such actions. Many participants of the study note that youngsters in Krasnodar krai are very creative and readily take part in activities aiming at the development of creativity.

Events timed to celebrations and festivals are attractive for youth. 'In the evening during the city day films about the history of the city are shown on a big screen. Every year there is another film, it is completed with frames shot during the events of the year. If you take part in these events, you may see yourself in that film'. Thanks to such events, young people understand that they are part of their city and part of its history.

Participants of focus groups notice that today subjects of educational policy in the region make efforts to combine young people's or children's recreation with getting knowledge: 'In the past camps were entertaining, now they are more developmental'.

Also other traditional subjects of youth's identity formation in the cultural and educational environment are named in focus group interview. These are theaters and museums of Krasnodar krai. Respondents mention that the young of the region go on excursion to ethnic village 'Ataman', but schools especially those situated in the countryside experience difficulties in getting there. 'Now in order to go somewhere lots of documents and agreements are needed. City schools can afford it, country ones do not have enough resources'.

According to the opinion of those questioned, it is important to form tolerance to members of various ethnic groups from early childhood because Krasnodar krai is a multinational region.

\section{CONCLUSION}

The cultural and educational environment of a region is a space where cultural and educational institutions, as well as other subjects (including new actors) interact to construct youth's regional identity. This environment plays a crucial role in the process, creating conditions for the actualization of significant past and preserving values and traditions essential for regional community, combining these conditions with innovative cultural and educational practices for the formation of stable regional identity and favorable image of future for youth.

Krasnodar krai has plenty of experience relating to the formation of youth's regional identity in the cultural and educational environment. A new generation of young people have grown up since the introduction of 'Kubanology' to educational programs of Krasnodar krai. This discipline effectively creates the awareness of regional history, nature, geography, culture, social and ethnic situation. Cultural and educational institutions not only shape the system of knowledge concerning local history and culture, but also develop affection to small motherland and stimulate values and behavior patterns linked to perspectives of Krasnodar krai.

It should be noted that activities of educational and cultural institutions remain at a high level. The work of these institutions includes various forms of interaction with youth by using such identity construction mechanisms as legal, organizational and informational.

Arguments mentioned may be justified by the results of empirical study, carried out by the authors. Young people recognize the role of cultural and educational environment in the construction of youth's regional identity, estimate activities of traditional actors as effective, display interest in actions of new subjects.

\section{REFERENCES}

[1] F.W. Morgan, Three aspects of regional consciousness. Sociological Review. 1939. №31, pp. 68-88. 
[2] D. Seamon, J. Sowers, Place and Placelessness, Edward Relph. URL: http://www.researchgate.net/profile/David_Seamon/publication/2620 08334_Place_and_Placelessness_Edward_Relph.

[3] M.V. Nazukina, Regional Identity // Political identity and politics of identity: in 2 vol. Vol. 1: Identity as a category of political science: Dictionary of terms and concepts / Ed. by I.S. Semenenko. Moscow: Russian political encyclopedia (ROSSPEN), 2011, pp. 143-147.

[4] L.A. Maksimova, R.A. Valiev, N.B. Ruzhenceva, T.V. Valieva, Regional identity in adolescence as a marker of personal connection with the territory of residence // Phycology and education. 2019. Vol. 24. № 2, pp. 82-92.

[5] E.V. Khlyscheva, Dynamics of ethno-confessional identities in the cultural landscape of the Astrakhan region // South-Russian Journal of Social Sciences. 2019. Vol. 20. №1. P. 112. URL: http://chsu.kubsu.ru/arhiv/2019_1/105-122.pdf

[6] J.A. Zubok, T.K. Rostovskaja, N.L. Smakotina, Youth and youth policy in modern Russian society. Moscow: ITD 'PERSPEKTIVA', 2016, p. 4.

[7] M.P. Artamonova, The cultural and educational environment of the school as a space for the socialization of juveniles in modern society // The theory and practice of social development. 2014. № 12, pp. 74$77 . \quad$ URL: http://teoriapractica.ru/rus/files/arhiv_zhurnala/2014/12/pedagogika/artamonova. pdf.

[8] E.S. Mertens, The development of the cultural and educational environment of Smolensk province in the second half of the XIX early XX centuries: abstract of the dissertation of the candidate of pedagogy. Smolensk. 2006.

[9] I.J. Murzina, Regional cultural and educational space: structure, functions, sociocultural potential. Moscow: Pero. 2014.

[10] E.P. Belozercev, Cultural and educational environment - myth or reality, tradition or innovation // Humanitarian: scientific and journalistic almanac. 2008. № 7, pp. 182-189.

[11] O.A. Borisko, S.A. Mirontseva, Influence of cultural and educational environment of the region on the formation of a regional youth identity // Human. Community. Management. 2017. Vol. 18. № 1, p. 20.

URL: http://chsu.kubsu.ru/arhiv/2017_1/2017_1_BoriskoMirontseva.pdf

[12] The official website of Krasnodar State Historical and Archaeological Museum of E.D. Felitsyn / The news. URL: https://felicina.ru/news.

[13] Youth web portal of Krasnodar krai. URL: https://molod.info/.

[14] The official website of state autonomous institution of culture "'Ataman' exhibition center" (Krasnodar krai). URL: http://www.atamani.ru/.

[15] The official website of 'My city voice' in Krasnodar. URL: https://mycityvoice.ru/krd 